\title{
Will we need oil in 2060?
}

\section{RJ Romero*}

Research in Engineering and Applied Sciences, Autonomous University of the State of Morelos, Mexico

*Corresponding author: RJ Romero, Research in Engineering and Applied Sciences, Autonomous University of the State of Morelos, Morelos, Mexico.

Submission: 㭰 February 24, 2018; Published: 望眥 March 06, 2018

\section{Opinion}

Since long time ago, in the early 1840 at the end of the Industrial revolution, we found than oil was a very useful energy vector. Now, we use items for our life that were produce with some energy transformation. In the near future, perhaps 2020, the energy transformation will not change a lot. Data from International Energy Agency (iea.org) show great energy dependence from coal, natural gas and oil.

Registered anomaly temperature since 1880 to 2010 show a tendency: there is a climate change. Of course the human activities are the cause for this phenomenon. Even if we replace all process with another fuel into combustion, the $\mathrm{CO}_{2}$ will be part of the stoichiometry reaction and this will never diminish while combustion will be.

In fact, all renewable energy process use devices than came from process with oil reaction, then in the present day, global

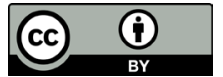

Creative Commons Attribution 4.0 International License

For possible submissions Click Here Submit Article energy needs oil for humanity activities. But, in the future? In 2060: we will need oil? Yes. We will need about a 99EJ (99x10^18J) in 2060 from Energy Technology Perspectives 2017 report edited by International Energy Agency. This is a $54.39 \%$ of the transformed oil in 2014. This value implies that we need to work in most efficiency transformation of the fuel. Not only of oil fuel, must all transformations be improved.

At 2060 we need $35 \%$ of renewable energy in our world energy transformation and 38\% of efficiency energy transformation in all levels: refineries, oil products, electricity and power or cogeneration plants. If we do not do an effort to develop now the new efficient process in petrochemical science we will not provide the energy that we will need in the future. All (renewable and conventional) energy process needs to be analyzed, evaluated and integrated for the new world. Oil fuels do exist and this help us to create the new balanced energy future energy system.

\section{Your subsequent submission with Crimson Publishers} will attain the below benefits

- High-level peer review and editorial services

- Freely accessible online immediately upon publication

- Authors retain the copyright to their work

- Licensing it under a Creative Commons license

- Visibility through different online platforms

- Global attainment for your research

- Article availability in different formats (Pdf, E-pub, Full Text)

- Endless customer service

- Reasonable Membership services

- Reprints availability upon request

- One step article tracking system 